УДК 616.126:612.17

\title{
Використання теплової кров’яної кардіоплегії при протезуванні клапанів серця
}

\author{
Кланца А. І., Терехівська О. В. \\ Хмельницька обласна лікарня
}

\begin{abstract}
Мета роботи - оцінка захисту міокарда із застосуванням інтермітентної антеградної теплової кров'яної кардіоплегії порівняно з фармакохолодовою в умовах штучного кровообігу.

Матеріали та методи. Основу дослідження склали пацієнти, яким проведено протезування аортального або мітрального клапана серця в умовах штучного кровообігу за період 2016-2017 рр. Дослідну групу становили 80 хворих, у яких методом кардіопротекції використовували теплову кров'яну кардіоплегію, контрольну групу - 80 пацієнтів, у яких застосовано кристалоїдну холодову кардіоплегію. Відбір і розподіл пацієнтів у групи відбувався шляхом довільної рандомізації.

Аналізували частоту застосування кардіоверсії після реперфузії, кількість спонтанних відновлень серцевого ритму, рівні КФК-МВ, трансаміназ, потребу в інотропній підтримці протягом раннього післяопераційного періоду. Лабораторні та інструментальні дослідження аналізували протягом перших 48 годин після втручання.

Результати. Незважаючи на технічно складніший процес проведення теплової кров'яної кардіоплегії, виявлено такі переваги: у контрольній групі відзначено меншу кількість хворих, у яких застосовували кардіоверсію після реперфузії; атріовентрикулярну блокаду II-III ступеня, яка потребувала додаткової електрокардіостимуляції, реєстрували з однаковою частотою; кількість пацієнтів, які потребували інотропної підтримки в перші дні, була значно більшою у другій групі; середня тривалість перебування в палаті інтенсивної терапії становила $24 \pm 8$ год. для першої групи і $29 \pm 7$ год. для другої групи. Ушкодження міокарда були меншими в першій групі, що корелює з істотними відмінностями щодо рівнів КФК-МВ.
\end{abstract}

Ключові слова: теплова кров'яна кардіоплегія, кристалоїдна кардіоплегія, захист, міокард.

Проблема захисту міокарда при операціях зі штучним кровообігом знаходиться на межі кардіохірургії, кардіоанестезіології та перфузіології. В жодному розділі оперативної кардіології, напевно, немає такого поліморфізму в підходах та оцінках, як з проблемі захисту міокарда. Практично в кожному великому кардіохірургічному центрі наявний «свій» підхід до цієї проблеми. Захист міокарда є суттєвою умовою успіху операцій на відкритому серці зі штучним кровообігом.

За останні десятиліття застосування кардіоплегічних розчинів на основі крові набуло значного поширення. На думку багатьох авторів, цей метод має безсумнівні переваги порівняно з іншими методами кардіопротекції, а саме - порівняно з кристалоїдною кардіоплегією, проте досі залишається багато відкритих питань щодо температури кров'яного кардіоплегічного розчину.

Перевагами кров'яної кардіоплегії є: а) висока киснева ємність еритроцитів, що забезпечує аеробний метаболізм міокарда, відповідно, і збереження пулу високоенергетичних фосфатів у період перетиснення аорти; б) висока буферна ємність еритроцитів, особливо груп гістидину та імідазолу, що дозволяє нейтралізувати кислі продукти метаболізму; в) адекватний ко- лоїдно-осмотичний тиск, який попереджує розвиток клітинного набряку; г) наявність вільних радикалів в еритроцитах; д) зниження загальної гемодилюції за час операції, що особливо актуально при тривалому періоді ішемії [5].

Значущість кров'яних розчинів для підтримки аеробного метаболізму в період ішемії добре вивчена в експериментальних і клінічних дослідженнях. Як в артеріальних, так і у венозних відділах мікросудин відсутні вогнища гіперосміронової цитоплазми, майже позбавленої піноцитозних везикул, а, навпаки, спостерігався високий ступінь везикуляції ендотеліоцитів. Отримані результати свідчать про більш високу протиішемічну активність кров'яної протекції міокарда порівняно з кристалоїдною, що особливо проявляється при тривалих періодах перетиснення аорти [6, 7]. Наразі 70\% кардіохірургів Північної Америки успішно виконують операції із застосуванням різних варіантів кров'яної кардіоплегії, натомість в Україні досі переважає кристалоїдна кардіоплегія.

Мета роботи - оцінка захисту міокарда із застосуванням інтермітентної антеградної теплової кров'яної кардіоплегії порівняно з фармакохолодовою в умовах штучного кровообігу. 
Матеріали та методи. Основу дослідження склали пацієнти, яким проведено протезування аортального або мітрального клапана серця в умовах штучного кровообігу за період 2016-2017 pp. у відділенні кардіо-ендоваскулярної хірургії Хмельницької обласної лікарні. Поділ на групи здійснювався залежно від виду кардіоплегії. Дослідну групу становили 80 хворих, у яких методом кардіопротекції використовували теплову кров’яну кардіоплегію, контрольну групу - 80 пацієнтів, у яких застосовано кристалоїдну холодову кардіоплегію. Предметом аналізу були: частота застосування кардіоверсії після реперфузії, кількість спонтанних відновлень серцевого ритму, рівні КФК-МВ, трансаміназ, потреба в інотропній підтримці протягом раннього післяопераційного періоду. Лабораторні та інструментальні дослідження аналізували протягом перших 48 год. після втручання.

Дослідження проводили у двох клінічних групах пацієнтів, які не мали значущих відмінностей у передопераційних клінічних умовах (табл. 1) і не мали супутніх коронарних уражень.

Операції виконувались одним складом бригади за стандартною методикою. Кров'яна кардіоплегія потребує певної схеми: до початку операції в стерильних умовах готується розчин, основу якого становить $\mathrm{KCl} 7,5 \%$ та розчин $\mathrm{MgSO}_{4} 25 \%$ у співвідношенні 4:1, що під'єднується до шприцевого дозатора, з'єднаного 3 магістраллю, яка відходить від оксигенатора та вводиться через окремий роликовий насос за розрахунковим співвідношенням швидкостей кардіоплегічного насоса для перфузату і насоса для калієвмісного розчину. Температура кардіоплегічного розчину корелює 3 температурою тіла $-34-35^{\circ} \mathrm{C}$. Розрахунокова доза кардіоплегічного розчину для болюсу еквівалентна 16 ммоль калію, підтримуюча - 8-10 ммоль калію.

Після перетиснення аорти введення кардіоплегії здійснювалось антеградно при заміні мітрального клапана, прямо в коронарні артерії - при протезуванні

\section{Таблиця 1}

Клінічні характеристики пацієнтів

Теплова кров'яна Холодова кристалоїдна

Характеристика кардіоплегія кардіоплегія

Чоловіки/Жінки 44/36 49/31

Вік 57,4 $59 \quad 55,8 \pm 10$

Euro SCORE $\quad 1,23-1,42 \% \quad 1,25-1,44 \%$

NYHA class III $\quad 64 \quad 62$

NYHA class IV $16 \quad 18$

Кліренс

креатиніну

$97 \pm 8$ мл/год.

$93 \pm 9$

Середній час пеертиснення аорти аортального клапана. Тривалість введення кардіоплегічного розчину становила 4-6 хв., повторне введення

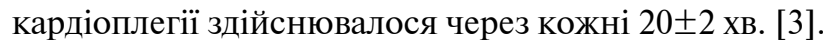

Результати та обговорення. В обох групах пацієнтів у термін 30 діб після оперативного втручання вижили всі. В усіх пацієнтів отримано хороший та задовільний результат операції, і всі вони були виписані зі стаціонару на 7-8-й день без клінічно значущих ускладнень.

Фібриляція шлуночків (ФШ), що потребувала електричної кардіоверсії, спостерігалась у ранньому реперфузійному періоді в першій групі (теплова кров'яна кардіоплегія) у 25 пацієнтів (31,25\%), спонтанне відновлення серцевої діяльності - у 55 хворих $(68,75 \%)$. У групі з використанням кристалоїдної холодової кардіоплегії ФШ мала місце у 57 осіб (71,25\%), спонтанне відновлення ритму - у 23 осіб $(28,75 \%)$.

АВ-блокада II-III ступеня, яка потребувала електрокардіостимуляції, однаково часто спостерігалась в обох дослідних групах.

У більшості пацієнтів у післяопераційному періоді відмічалось підвищення МВ фракції креатинфосфокі-

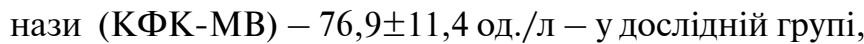
$130 \pm 25,7$ од./л - в контрольній групі, хоча різниця не була достовірною. Збільшений рівень КФК-МВ спостерігався перші 6-8 годин після операції, повернення до норми відбувалося протягом 2-3 діб, що відповідає даним літератури [1].

Показники аспартатамінотрансферази в якості маркера ураження міокарда були дещо підвищені і суттєво не відрізнялися в обох досліджуваних групах.

Інотропна підтримка застосовувалась у ранньому післяопераційному періоді у більшого відсотка пацієнтів у контрольній групі. Із 80 пацієнтів дослідної групи симпатоміметики отримували $11(13,75 \%)$, у другій групі із 80 хворих - 19 (23,75\%), доза коливалась у межax 4-6 мкг/кг/хв., тривалість становила 12-24 год.

\section{Таблиця 2}

Схема проведення теплої кровяної кардіоплегії

\begin{tabular}{ll} 
Спосіб введення & $\begin{array}{l}\text { Корінь аорти, коронарні } \\
\text { артерії }\end{array}$ \\
\hline Тиск у магістралі & $\begin{array}{l}\text { Не більше } 130 \mathrm{MmHg}-\text { для } \\
\text { аорти, не більше } 80 \mathrm{MmHg}- \\
\text { для коронарів }\end{array}$ \\
\hline $\begin{array}{l}\text { Швидкість кардіоплегічного } \\
\text { насосу }\end{array}$ & 300 мл/год. \\
\hline $\begin{array}{l}\text { Перша доза відразу після } \\
\text { перетиснення }\end{array}$ & $\mathrm{KCl} 200$ мл/год. \\
\hline $\begin{array}{l}\text { Друга доза (після 15-20 } \\
\text { хвилин) }\end{array}$ & $\mathrm{KCl} 90$ мл/год. \\
\hline $\begin{array}{l}\text { Третя доза (після 15-20 } \\
\text { хвилин) }\end{array}$ & $\mathrm{KCl} 60$ мл/год. \\
\hline $\begin{array}{l}\text { Четверта доза (і наступні) } \\
\text { кожні 25 хв. }\end{array}$ & $\mathrm{KCl} 60-40$ мл/год.
\end{tabular}


Екстубація пацієнтів виконувалася через

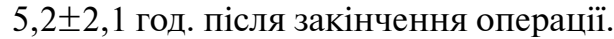

Середня тривалість перебування в палаті інтенсив-

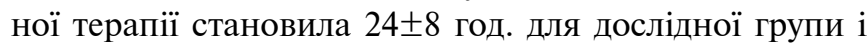
$29 \pm 7$ год. - для контрольної групи дослідження.

Отримані результати свідчать про ефективність і безпечність використання теплової кров'яної кардіоплегіï.

Позитивними моментами використання калієвомагнієвої суміші на основі аутокрові $є$ забезпечення деполяризації міокардіоцитів і зупинка серцевої діяльності, разом із цим перешкоджання переходу іонів кальцію у внутрішньоклітинний простір за рахунок конкуруючої дії іонів магнію. Тим самим усувається можливість виникнення «кальцієвого парадоксу» - основного фактору реперфузійного ушкодження міокарда [4]. Крім того, метод дозволяє уникати надлишкової гемодилюції та ускладнень, пов'язаних з інтерстиційними набряками тканин і внутрішніх органів [2].

Висновки. Результати дослідження вказують на ефективність кардіопротекції на основі крові: неглибокі ультраструктурні ознаки ішемічно-реперфузійних ушкоджень міокарда, повноцінне відновлення функцій міокарда, високу частоту спонтанного відновлення синусового ритму і меншу кількість аритмій у відновлювальному періоді.

Переривчаста теплова кров'яна кардіоплегія позитивно впливає на деякі клінічні показники та біохімічні параметри у хворих у ранньому післяопераційному періоді. Вона демонструє певну тенденцію до кращого захисту міокарда, хоч і не достовірно, та може вважатися безпечним способом кардіопротекції і легко використовуватися в інших кардіохірургічних центрах України.

\section{Література}

1. Diagnosis of perioperative myocardial infarction by considering relationship of postoperative electrocardiogram charyes and enzyme increases after coronary bypass operations / Criesmacher A., Grinm M., Schreiner W. et al. // Clin. Chem. - 1990. - Vol. 36. - P. 883-887.

2. Buckberg, G. D. \& Athanasuleas, C. L. Cardioplegia: solution or strategies? // Eur. J. Cardiothorac. Surg. 2016. - Vol. 50. - P. 787-791

3. Durandy, Y. D. Is there a rationale for shot cardioplegia re-dosing intervals? // Word J. Cardiol. -2015. - Vol. 7. P. 658-664.

4. Barboza de Oliveira, M. A., Brandi, A. C. \& dos Santos, C. A. Modes of induced cardiac arrest: hyperkalemia and hypocalcemia - literature review // Rev. Bras. Cir. Cardiovasc - 2014. - Vol. 29 (3). - P. 432-436.

5. Is cold or warm cardioplegia superior for myocardial protection? / Abah U., Roberts P. G., Ishaq M. \& De Silva R. // Interact. Cardiovasc. Thorac. Surg. 2012. - Vol. 14. - P. 848-855.

6. Cold blood versus crystalloid cardioplegia for myocardial protection in adult cardiac surgery: a metaanalysis of randomized controlled studies / Zeng, J. et al. // J. Cardiothorac. Vasc. Anesth. - 2014. Vol. 28. - P. 674-681.

7. Ascione R, Suleiman S. M., Angelini G. D. Retrograde hotshot cardioplegia in patients with left ventricular hypertrophy undergoing aortic valve replacement // Ann Thorac Surg. 2008. - Vol. 85. - P. 454-458.

\title{
Using of the warm blood cardioplegia in cardio valve replacement
}

\author{
Klantsa A., Terekhivska O. \\ Khmelnitskiy regional hospital
}

The purpose of the work is to evaluate the protection of the myocardium using intermittent antegrade, warm blood cardioplegia in comparison with pharmacold cardioplegia under the conditions of artificial blood circulation.

Materials and methods. The study was based on the patients who had aortic or mitral valve replacement under the conditions of artificial blood circulation in 2016-2017. We observed about 80 patients in the first group (in which we used warm blood cordioplegia as the cardioprotection method), and 80 patients in the second category (for whom we used crystalloid cold cardioplegia). Selection and distribution of patients in the groups was done randomly.

We analyzed the frequency of cardioversion use after reperfusion, the number of spontaneous cardiac rhythm restorations, creatine phosphokinase-MB levels, transaminase levels, and the need for inotropic support during the early postoperative period. Laboratory and instrumental studies were performed during the first two days after cardiac surgery.

Results. Despite the technically more complicated process of conducting warm blood cardioplegia, the following benefits have been identified: in the first group we identified a lower number of patients for whom cardioversion after reperfusion was used; atrioventricular blockade of II-III degrees, requiring additional cardiac pacing, was registered with the same frequency; the number of patients who needed inotropic support in the early days was significantly higher in the second group; the average length of stay in the intensive care ward was (24 \pm 8 hours) for the first group of study and up to (29 \pm 7 hours) for the second group. The damage to the myocardium was lower in the first group, which correlated with significant differences in the levels of creatine phosphokinase-MB.

Key words: warm, blood cardyoplegia, crystalloid cardioplegia, protection, myocardium. 


\title{
Использование тепловой кровяной кардиоплегии при протезировании клапанов сердца
}

\author{
Кланца А. И., Тереховская О. В.
}

Хмельницкая областная больница

Цель работы - оценка защиты миокарда с применением интермитирующей антеградной тепловой кровяной кардиоплегии по сравнению с фармакохолодовой в условиях искусственного кровообращения.

Материалы и методы. Основу исследования составили пациенты, которым было проведено протезирование аортального или митрального клапана сердца в условиях искусственного кровообращения за период 2016-2017 гг. Под нашим наблюдением находилось 80 пациентов первой группы, у которых в качестве метода кардиопротекции использовали тепловую кровяную кардиоплегию, и 80 пациентов второй (контрольной) группы, у которых использовалась кристаллоидная холодовая кардиоплегия. Отбор и распределение пациентов по группам осуществлялся путем произвольной рандомизации.

Анализировали частоту применения кардиоверсии после реперфузии, количество спонтанных восстановлений сердечного ритма, уровни КФК-МВ, трансаминаз, потребность в применении инотропной поддержки на протяжении раннего послеоперационного периода. Лабораторные и инструментальные обследования проводили в первые два дня после кардиохирургического вмешательства.

Результаты и обсуждение. Несмотря на технически более сложный процесс проведения тепловой кровяной кардиоплегии, определен ряд преимуществ: в исследуемой группе отмечено меньшее количество больных, у которых применяли кардиоверсию после реперфузии; атриовентрикулярную блокаду II-III степени, требующую дополнительной электрокардиостимуляции, регистрировали с одинаковой частотой; количество пациентов, нуждающихся в инотропной поддержке в первые дни, было значительно больше во второй группе; средняя продолжительность пребывания в палате интенсивной терапии составила $24 \pm 8$ часов для первой группы исследуемых и $29 \pm 7$ часов для второй группы. Повреждения миокарда были меньше в первой группе, что коррелирует с существенными отличиями уровней КФК-МВ.

Ключевые слова: тепловая кровяная кардиоплегия, кристаллоидная кардиоплегия, защита, миокард. 